\title{
A Modified Carbon Paste Sensor for Determination of Zn in Vitamin and Waste Water using Thiosemicarbazide and Acetaldehyde Thiosemicarbazone Complexes
}

\author{
Khorshid $\mathrm{AF}^{\text {**, }}$, Yosry M Issa ${ }^{2}$ and Ragab R Ami ${ }^{3}$ \\ ${ }^{1}$ Pharmaceutical Analytical Chemistry Department, Nahda University, NUB, New Beni-Sueff, Egypt \\ ${ }^{2}$ Basic and Applied Science Department, Nahda University, NUB, New Beni-Sueff, Egypt \\ ${ }^{3}$ Chemistry Department, Cairo University, Giza, Egypt
}

\begin{abstract}
A novel carbon paste Zinc (II) ion-chemically modified carbon paste sensors highly selective and sensitive (CMCPE) based on the metal complexes $\mathrm{Zn}$ - incorporating thiosemicarbazide, $\left[\mathrm{Zn}(\mathrm{TS})_{2}(\mathrm{ac})_{2}\right] . \mathrm{C}_{2} \mathrm{H}_{5} \mathrm{OH}$ ( $\mathrm{Zn}-\mathrm{TSC}$ ) and $\mathrm{Zn}$-acetaldehyde thiosemicarbazone $\left[\mathrm{Zn}(\mathrm{ATS})_{2}\right] .4 \mathrm{H}_{2} \mathrm{O}(\mathrm{Zn}-\mathrm{ATSC})$ dissolved in tricresyl phthalate (TCP) as binder liquid. The chemically modified sensors were developed for determination of Zinc (II) in vitamin and waste water. The constructed sensors showed good linear response of Nernstian slopes $32.5 \pm 0.5$ and $28.5 \pm 0.5 \mathrm{mV}$ per decade over the concentration range of $5.0 \times 10^{-8}-2.0 \times 10^{-3}$ and $6.3 \times 10^{-8}-7.9 \times 10^{-3} \mathrm{M}$ with a detection limit of 0.25 and $0.50 \mathrm{nM}$ for (Zn-TSC) and (Zn-ATSC) ions respectively. The selectivity coefficients of the proposed sensors revealed very good selectivity with respect to alkali, alkaline earth and some transition metal ions and could be used in $\mathrm{pH}$ range of 3.5-8.0. As a result the proposed sensors were successfully applied to (Zn- TSC) or (Zn- ATSC) ions determination in mixture solutions, multivitamins and wastewater samples and as an indicator sensors for potentiometric titration of $\mathrm{Zn}^{2+}$ with EDTA. The isolated complexes, (Zn- TSC) or (Zn- ATSC) were synthesized by the anodic dissolution of Zinc metal in an anhydrous acetone solution of the ligands where TSC is thiosemicarbazide, ATSC is acetaldehyde thiosemicarbazone ligand and ac = acetone. Applications of the proposed sensors to the determination of zinc as an indicator sensor for potentiometric titration of Zinc (II) ion with EDTA are successfully applied. The obtained results were compared using the US Pharmacopeia method and there is no significant difference was observed.
\end{abstract}

Keywords: Carbon paste sensor; Zinc complexes; Zinc vitamin; Waste water; Thiosemicarbazide; Acetaldehydethiosemicarbazone; Potentiometric

\section{Introduction}

Zinc is one of the most functioning metals necessary for more than three hundred different enzymes [1], so plays a very vital role in a large number of biological processes. As it is a cofactor for the antioxidant enzyme superoxide dismutase (SOD) with a number of enzymatic reactions involved in carbohydrate and protein metabolism. Its natural killer cells and interleukin-2 immune-enhancing activities include regulation of $\mathrm{T}$ lymphocytes, $\mathrm{CD} 4$ cells, so possesses antiviral activity. In addition, controls the release of stored vitamin A from the liver so, regulates insulin activity and promote the conversion thyroid hormones thyroxine to triiodothyronine. Zinc plays a role in wound healing, especially following burns or surgical incisions, Wilson's disease, herpes, taste or smell disorders, diabetes, and diabetic neuropathy and use in the prevention of the common cold. The over dose can consider as toxicity which may cause severe anemia, stomach cramps, nausea, and vomiting, renal failure, pulmonary manifestations while deficiency in the diet cause slow wound healing, decreased immune function, loss of appetite, poorly sperm production in male organ and stimulate the formation of $\alpha$-amyloid which causes Alzheimer's disease so it's very important to determine and detect trace quantities of zinc. Several analytical methods has been used for the determination of zinc ion, as flame atomic absorption [2], spectrometry UV-Vis spectroscopy [3], potentiometry [4], fluorescence [5,6] and inductively coupled plasma atomic emission spectrometry (ICPAES) [7]. These techniques have some limitations due to the completely filled d-orbital of zinc ion, which results in an absence of suitable spectroscopic or magnetic signals. Beside other analytical tools, different zinc ion selective sensors based on many ionophores have been reported [8]. Although all ISE methods used for determination of $\mathrm{Zn}$ are acceptable but most of them suffer from have poor selectivity [9-18], sensitivity and stability, long response time and short life time [19-28]. In addition, there is no method in the literature for the analysis and determination of $\mathrm{Zn}$ by chemical modified carbon paste sensor (Zn-CMCPS). The advantages of CMCPs are short measurement time, adequate precision, wide analytical ranges, high accuracy, low cost, small size sensors, low detection limits and simple to design.

In this work, suggested new types of an octahedral structure of zinc (II) complexes based on thiosemicarzide and acetyl thiosemicarbazone as shown in Figure 1. (Zn-TSC) or (Zn-ATSC) were synthesized for the determination of zinc in pure state, vitamin and waste water by construction of $\mathrm{Zn}$-CMCPS which were dissolved in tricresyl phthalate (TCP) as liquid binder mediator and the electrochemical performance characteristics of the proposed sensors were studied.

\section{Materials and Methods}

\section{The electrochemical system}

Laboratory potential measurements were performed using Jenway

*Corresponding author: Khorshid AF, Pharmaceutical Analytical Chemistry Department, Nahda University, NUB, New Beni-Sueff, Egypt, Tel: +20822284680; E-mail: amalkorshid@yahoo.com

Received May 25, 2015; Accepted August 03, 2015; Published August 10, 2015

Citation: Khorshid AF, Issa YM, Ami RR (2015) A Modified Carbon Paste Sensor for Determination of $\mathrm{Zn}$ in Vitamin and Waste Water using Thiosemicarbazide and Acetaldehyde Thiosemicarbazone Complexes. J Biosens Bioelectron 6: 176 doi:10.4172/2155-6210.1000176

Copyright: (c) 2015 Khorshid AF, et al. This is an open-access article distributed under the terms of the Creative Commons Attribution License, which permits unrestricted use, distribution, and reproduction in any medium, provided the original author and source are credited. 


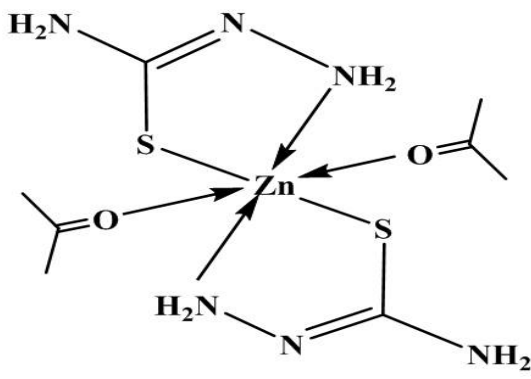

Figure 1: Suggested Octahedral Structure for Zinc(II) Complexes of Thiosemicarbazide and Acetyl thiosemicarbazone.<smiles>C/C=N/NC(N)=S</smiles>

TSC

ATSC

Figure 2: The structures of Thiosemicarbazide and Acetaldehyde Thiosemicarbazone.

(3505 and 3510) digital $\mathrm{pH} / \mathrm{mV}$ meters. The ruggedness and $\mathrm{pH}$ were done using the same pervious system at $25 \pm 1^{\circ} \mathrm{C}$. An external reference electrode is a saturated calomel electrode (SCE). All EMF measurements were carried out with the following assembly: $\mathrm{Hg}$, $\mathrm{Hg}_{2} \mathrm{Cl}_{2}(\mathrm{~s}), \mathrm{KCl}$ (sat.) sample solution carbon paste sensor. A calibrated microcomputer conductivity meter [Jenway, 4310 digital] was used for conductance measurements.

\section{Reagents and materials}

All chemicals used were of analytical reagent grade. Doubly distilled water was used throughout all the experiments. Grade pure graphite powders, tricresyl phthalate (TCP), dioctyl phthalate (DOP), tributyl phthalate (TBP), dibutyl phthalate (DBP), as well as all metal salts such as chlorides, nitrates and sulphates were purchased from Aldrich. The metal (Alfa Inorganics) used; $\mathrm{Zn}$ was purchased in the form of rods ( 2 $\mathrm{cm} \times 2 \mathrm{~cm}, 2-3 \mathrm{~mm}$ thick). Octozinc ( $25 \mathrm{mg} /$ capsule) were provided by October Pharma S.A.E. - Egypt. The oxide surface was removed by treating the metal with conc. $\mathrm{HNO}_{3}$ for several minutes and then washing with distilled water.

\section{The organic compounds}

Thiosemicarbazide is a standard material was received from Fluka and Acetaldehyde Thiosemicarbazone was prepared by adding an alcoholic solution of acetaldehyde $25 \%$ ( $38 \mathrm{ml} \approx 0.2 \mathrm{~mol}$ ) to alcoholic solution of thiosemicarbazide $(18.2 \mathrm{gm} \approx 0.2 \mathrm{~mol})$. The resulting yellowish white crystals were collected and washed with ethanol, diethyl ether. Yield $(20 \mathrm{gm} \approx 85.5 \%)$ and the melt point at $133^{\circ} \mathrm{C}$ (Figure 2 ). Electrochemical synthesis of thiosemicarbazide and
acetaldehydethiosemicarbazone Zinc complexes

Thiosemicarbazide $(0.46 \mathrm{~g}, 5 \mathrm{mM})$ was dissolved in at least amount $(5 \mathrm{ml})$ of $96 \%$ Ethanol and then $55 \mathrm{ml}$ of anhydrous acetone were added in presence of $1.5 \mathrm{mg} \mathrm{Et} \mathrm{NClO}_{4}$ dissolved in two drops of water. Electrolysis of Copper metal into $60 \mathrm{ml}$ of the previous thiosemicarbazide solution (HTS) at $20 \mathrm{~V}$ current was started led to dissolution of $63.5 \mathrm{mg}$ of $\mathrm{Zn}$ during $60 \mathrm{~min} .\left(\mathrm{E}_{\mathrm{f}}=0.5 \mathrm{~mol} . \mathrm{F}^{-1}\right)$. The insoluble material was collected and analyzed as [Zn (TSC) (TS) ${ }_{2}(\mathrm{ac})$ $\left.{ }_{2}\right]\left(\mathrm{C}_{2} \mathrm{H}_{5} \mathrm{OH}\right)$.

[Zn (ATSC) $\left.{ }_{2}(\mathrm{ac})\left(\mathrm{H}_{2} \mathrm{O}\right)\right] .\left(\mathrm{H}_{2} \mathrm{O}\right)$ was prepared by the same procedure.

\section{Elemental, spectral and thermal measurements}

Carbon, hydrogen and nitrogen contents were determined using a Perkin-Elmer CHN 2400 at Micro analytical Center, Cairo University, Egypt. Infrared spectra for the samples were recorded by Perkin Elmer FTIR 1605 using $\mathrm{KBr}$ pellets. Thermo gravimetric analysis (TGA and DTG) were carried out in dynamic nitrogen atmosphere $(30 \mathrm{ml} / \mathrm{min})$ with a heating rate of $10^{\circ} \mathrm{C} / \mathrm{min}$ using a Schimadzu TGA-50H thermal analyzer.

\section{Preparation of modified carbon paste sensors}

A modified carbon paste sensor is a Teflon holder (12 cm length) with a hole at one end ( $3.5 \mathrm{~mm}$ deep, $7 \mathrm{~mm}$ diameter) filling with carbon paste served as the sensor body. Chemically modified pastes of carbon were prepared by weighed amounts of several pastes of varying nature and ratios of (Zn-TSC) and/or (Zn- ATSC)/graphite/binder for the systematic investigation of each paste composition mixed with high purity graphite with acetone. Mix the mixture homogenized, left at room temperature to evaporate acetone, and then the impregnated carbon powder was added to weighed amount of tricresyl phthalate (TCP). The prepared paste was packed into the hole of the sensor holder body. The CP was smoothed onto paper until it had a shiny appearance and was used directly for potentiometric measurements without preconditioning requirements.

\section{Calibration of sensor}

Standard zinc solutions was added to $50 \mathrm{ml}$ doubly distilled water to cover the concentration range from $1.0 \times 10^{-7}$ to $1.0 \times 10^{-2} \mathrm{M}$. Lower concentrations were prepared by appropriate dilutions. The new ( $\mathrm{Zn}$ TSC) and/or (Zn- ATSC) CMCPEs sensor and the reference sensor were immersed in conjunction with the solution at $25 \pm 1^{\circ} \mathrm{C}$ and the emf value was recorded, after each addition, the values were plotted versus the negative logarithmic value of the zinc concentration (pZn) and the resulting graph was used for subsequent determination of unknown zinc concentration from the liner part of the curve (calibration curve method).

\section{Effect of $\mathrm{pH}$ on the sensor potential}

The influence of $\mathrm{pH}$ of the zinc solution on the potential response values of the paste sensor for (Zn-TSC) and/or (Zn- ATSC) was studied. Aliquots of the $\mathrm{Zn}$ solution $(50 \mathrm{ml})$ were transferred to $100 \mathrm{ml}$ titration cell and the tested $\mathrm{Zn}$-CMCPS in conjunction with the glass electrode for measuring $\mathrm{pH}$, calomel reference electrode, and a combined were immersed in the same solution. The $\mathrm{pH}$ and $\mathrm{mV}$ readings were simultaneously recorded. The $\mathrm{pH}$ of the solution was varied over the range of 1.0-10.0 by addition of very small volumes of $0.1 \mathrm{M} \mathrm{HNO}_{3}$ and/ or $(0.1-1.0 \mathrm{M}) \mathrm{NaOH}$ solution. Plot the $\mathrm{mV}$-readings against the $\mathrm{pH}$ values for the different concentrations.

\section{Selectivity of the sensors}

The selectivity coefficients of different interfering ions for the studied sensors, was determine according to the MPM [29,30], a reference solution $\left(\mathrm{a}_{\mathrm{A}}\right)$ is added an amount of the drug to give a final concentration of $\left(\mathrm{a}_{\mathrm{A}}^{-}\right)$, the shift in potential change $(\Delta \mathrm{E})$ is thus 
Citation: Khorshid AF, Issa YM, Ami RR (2015) A Modified Carbon Paste Sensor for Determination of Zn in Vitamin and Waste Water using Thiosemicarbazide and Acetaldehyde Thiosemicarbazone Complexes. J Biosens Bioelectron 6: 176. doi:10.4172/2155-6210.1000176

Page 3 of 8

measured. To a reference solution containing the same concentration $\left(\mathrm{a}_{\mathrm{A}}\right)$, a certain amount of interference ion that cause the same $(\Delta \mathrm{E})$ value is thus determined $\left(A_{i}\right)$.

$$
K_{Z n . J^{2+}}^{\text {POT }}=\frac{\left(a_{A}{ }^{j}-a_{A}\right)}{A_{j}}
$$

\section{Potentiometric determination}

The standard additions method: An increment of certain volumes of standard $\mathrm{Zn}$ solution was added to $50 \mathrm{ml}$ water containing different volumes of the zinc in its pure state, pharmaceutical preparation (Octozinc capsules), and in spiked samples of wastewater with known volumes of the zinc. The jump in $\mathrm{mV}$ reading was recording for each increment and used to calculate the concentration of the drug in sample solution using the following equation [31].

$$
\mathrm{Cx}=\mathrm{C}_{\mathrm{S}}\left(\frac{\mathrm{V}_{\mathrm{s}}}{\mathrm{V}_{\mathrm{x}}+\mathrm{V}_{\mathrm{s}}}\left(10^{\mathrm{n}(\Delta \mathrm{E} / / \mathrm{S})}-\right) \frac{\mathrm{V}_{\mathrm{X}}}{\mathrm{V}_{\mathrm{x}}+\mathrm{V}_{\mathrm{s}}}\right)^{-1}
$$

Where, Cx: the calculated concentration,

Vx: the volume of the original sample solution,

Vs and Cs: the volume and concentration of the standard solution added to the sample to be analyzed, respectively,

$\Delta \mathrm{E}$ : the change in potential after addition of certain volume of standard solution, and $\mathrm{S}$ : the slope of the calibration graph.

In the potentiometric titrations: Different weights ranged from $1.79-17.95 \mathrm{mg}$ of zinc were dissolved in $50 \mathrm{ml}$ by bi-distilled water. Different volumes of this solution (1.0-5.0 mL) were taken and subjected against $0.01 \mathrm{~N}$ EDTA using the sensor(s). Conventional $S$-shaped curves with first and second plots were used to determine the end points.

\section{Analysis of octozinc capsule}

20 capsules of (Octozinc $25 \mathrm{mg} /$ capsule) were powdered and weighed (200-250 mg) portion from each was mixed with $50 \mathrm{ml}$ doubly distilled water, using mechanical shaker for shaken in an about $30 \mathrm{~min}$, filtered into a $100 \mathrm{ml}$ volumetric flask; then the solution was filled to the mark with doubly distilled water and shaken. Different known amounts of the solution (1.0-10 ml) were putted and subjected to the potentiometric determination by the standard additions method.

\section{In spiked waste water}

The concentrations of different quantities from $1.0 \times 10^{-6}$ to $5.0 \times$ $10^{-4} \mathrm{M}$ zinc were putted in volumetric flask $100 \mathrm{ml}$ spiked with five $\mathrm{ml}$ waste water and shaking for $5 \mathrm{~min}$, then completed with doubly bidistilled water to the mark. A small volume of $0.01 \mathrm{M} \mathrm{HCl}(0.1-2.0$ $\mathrm{ml}$ ) was putted to adjust the $\mathrm{pH}$ from 4 to 5 . The spiked waste water was containing zinc was determined by the standard addition method.

\section{Content uniformity assay of octozinc capsule}

Ten individual capsules were placed in separate beaker $100 \mathrm{ml}$ and dissolved in distilled water. The different concentration of the solutions was determined by the standard addition method, as described above.

\section{Dissolution test}

The test was carried out according to the USP XXX method apparatus II [32]. One tablet (Octozinc capsule $25 \mathrm{mg}$ ) was placed in the vessel, and the dissolution medium ( $900 \mathrm{ml}$ bidistilled) was maintained at $37 \pm 0.5^{\circ} \mathrm{C}$. The vessel was rotated at $50 \mathrm{rpm}$. For the potentiometric determination, after an appropriate time interval (1.0$2.0 \mathrm{sec}$ ), the potential values were recorded, and the amount of the zinc was calculated from the calibration graph. For the conductimetric measurements, introduce the conductmetric electrode in the vessel every two seconds without hindering the motion and take the reading by $\mu$ s.

\section{Results and Discussion}

Measurements of the electrochemical efficiency, $E_{f}$, defined as moles of metal dissolved per Faraday of electricity, for the $\mathrm{Zn} / \mathrm{L}$ system (where $\mathrm{L}=$ ligand) gave $\mathrm{E}_{\mathrm{f}}=0.5 \pm 0.05 \mathrm{molF}^{-1}$. The mechanism for Zinc anode dissolution is compatible with the following equations 1 and 2 $[32,33]$.

Mechanism for $\mathrm{Zn}$ (II) anodic dissolution:

$$
\begin{aligned}
& \text { Cathode: } 2 \mathrm{HATS}+2 \mathrm{e} \rightarrow 2 \text { (ATS) }^{-}+\mathrm{H}_{2}(\mathrm{~g})(1)
\end{aligned}
$$

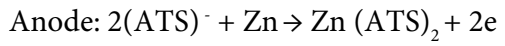

The elemental analysis of:

$$
\left[\mathrm{Zn}(\mathrm{TS})_{2}(\mathrm{ac})_{2}\right] .\left(\mathrm{C}_{2} \mathrm{H}_{5} \mathrm{OH}\right) \text { (M.wt 407.9) (yellowish white), is: }
$$

$\{\% \mathrm{C}=28.9(29.4), \% \mathrm{H}=6.14(6.42)$ and $\% \mathrm{~N}=20.3(20.6)\}$ while, [Zn(ATS) $\left.{ }_{2}\left(\mathrm{H}_{2} \mathrm{O}_{2}\right)\right]_{2}\left(\mathrm{H}_{2} \mathrm{O}\right)$ (M.wt 369.8) (Buff) is: $\{\% \mathrm{C}=18.67$ (19.49), $\% \mathrm{H}=4.98(5.45)$ and $\% \mathrm{~N}=22.37(22.73)\}$.

The complexes are air-stable, hygroscopic, with higher melting points, insoluble in $\mathrm{H}_{2} \mathrm{O}$ and most of organic solvents, but soluble in DMSO and DMF. The analytical data are in a good agreement with the proposed stoichiometry of the complexes.

\section{Characteristics of the sensor}

The electrochemical characteristics of the sensors were determined its sensitivity, linear range, detection limit, response time and selectivity coefficients. The graphite $(\mathrm{G}) /$ binder $(\mathrm{B})$ ratio, the nature and amount of the complex, are reported to significantly influence the sensitivity and selectivity of the sensor. Firstly, the sensor was preconditioned in stirred water until a steady potential was obtained before measurement. The influence of the binder type with its concentration on the characteristics of the studied sensors was investigated by using four binders with different polarities including TCP, DOP, DBP, and TBP.
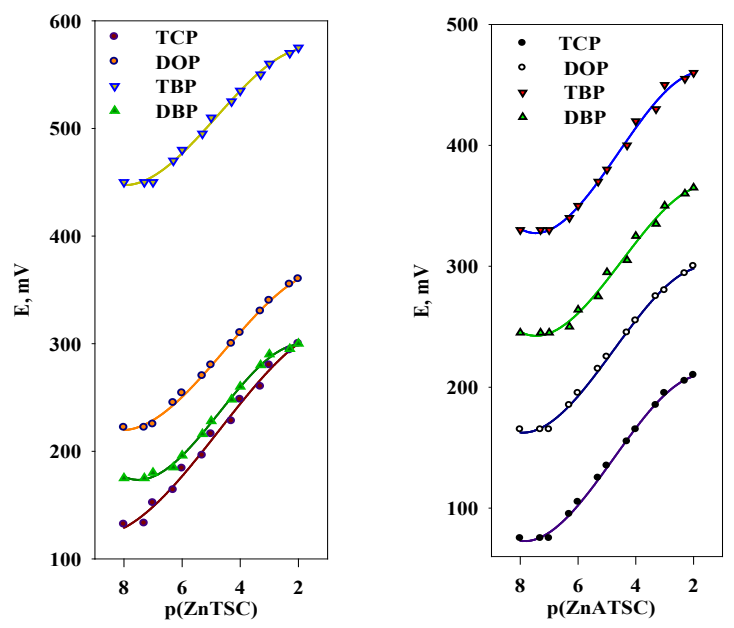

Figure 3: Effect of different binders on the response of ZnTSC and ZnATSC sensor. 
Citation: Khorshid AF, Issa YM, Ami RR (2015) A Modified Carbon Paste Sensor for Determination of Zn in Vitamin and Waste Water using Thiosemicarbazide and Acetaldehyde Thiosemicarbazone Complexes. J Biosens Bioelectron 6: 176. doi:10.4172/2155-6210.1000176

Page 4 of 8

Different binder/graphite $(\mathrm{w} / \mathrm{w})$ ratios were studied as shown in Figure 3, among the different compositions studied, a paste containing $1.0 \mathrm{wt} \% \mathrm{Zn}$-TSC or $1.0 \mathrm{wt} \%$ Zn-ATSC complexes, $55.0 \mathrm{wt} \%$ graphite, and $44.0 \mathrm{wt} \%$ TCP exhibited the best response characteristics also the lowest detection limit. Therefore, these compositions were used to study various operation parameters of the $\mathrm{Zn}$-sensors and the optimum compositions for the best sensors were given in Table 1. These sensors were chosen in this study and its electrochemical performance characteristics were systematically evaluated according to IUPAC recommendation $[34,35]$.

\section{Reproducibility of the sensor}

The sensor surface of the modified sensor is the main attraction that can be renewed after every use. The surface of modified sensor can be renewed by a little carbon paste squeezing out of the tube and a fresh surface is smoothed on a piece of weighing paper whenever needed. Accordingly, a suitable weight $(\sim 2.0 \mathrm{~g})$ of paste can be used at optimum composition.

The examination of the potential reading was taken for the repeatability of the Zn-TSC and Zn-ATSC sensors by the subsequent measurements in $1.0 \times 10^{-3} \mathrm{M} \mathrm{Zn}$ sulphate solution then followed by measuring the first set of solution at $1.0 \times 10^{-4} \mathrm{M} \mathrm{Zn}$ solution. The standard deviation values are given in Table 2 for each $\mathrm{Zn}$-sensor by measuring five replicate measurements emf. The values obtained indicate the repeatability is excellent of the potential response of the sensors.

\begin{tabular}{|c|c|c|c|c|c|c|c|c|}
\hline \multicolumn{2}{|c|}{ Composition (\%) } & \multirow[t]{3}{*}{ Binder } & \multirow[t]{3}{*}{ G\% } & \multirow[t]{3}{*}{ B\% } & \multirow[t]{3}{*}{$\mathbf{s}$} & \multirow[t]{3}{*}{ C.R. } & \multirow[t]{3}{*}{ LOD } & \multirow[t]{3}{*}{$\mathbf{R}_{\text {(s) }}$} \\
\hline \multicolumn{2}{|l|}{ Complexes } & & & & & & & \\
\hline Zn-TSC & & & & & & & & \\
\hline 0.5 & 1 & (TCP) & 55 & 44.5 & $29.5 \pm 0.0$ & $1.0 \times 10^{-7}-1.5 \times 10^{-3}$ & $1.5 \times 10^{-7}$ & $\leq 15$ \\
\hline $1.0^{*}$ & 2 & (TCP) & 55 & 44 & $32.5 \pm 0.5^{*}$ & $5.0 \times 10^{-8}-2.0 \times 10^{-3}$ & $2.5 \times 10^{-8}$ & $\leq 10$ \\
\hline 3 & 3 & (TCP) & 55 & 42 & $28.5 \pm 0.5$ & $1.5 \times 10^{-7}-1.0 \times 10^{-3}$ & $3.9 \times 10^{-8}$ & $\leq 14$ \\
\hline 0.5 & 4 & (DOP) & 55 & 44.5 & $28.5 \pm 0.5$ & $5.5 \times 10^{-7}-4.0 \times 10^{-3}$ & $4.2 \times 10^{-7}$ & $\leq 15$ \\
\hline 1 & 5 & (DOP) & 55 & 44 & $29.0 \pm 0.5$ & $4.6 \times 10^{-7}-2.0 \times 10^{-3}$ & $2.5 \times 10^{-7}$ & $\leq 10$ \\
\hline 3 & 6 & (DOP) & 55 & 42 & $29.5 \pm 0.5$ & $3.5 \times 10^{-7}-1.0 \times 10^{-3}$ & $1.0 \times 10^{-7}$ & $\leq 12$ \\
\hline 0.5 & 7 & $(\mathrm{TBP})$ & 55 & 44.5 & $24.0 \pm 0.5$ & $7.4 \times 10^{-7}-2.0 \times 10^{-3}$ & $6.5 \times 10^{-7}$ & $\leq 15$ \\
\hline 1 & 8 & (TBP) & 55 & 44 & $25.5 \pm 0.5$ & $6.3 \times 10^{-7}-1.5 \times 10^{-3}$ & $5.0 \times 10^{-7}$ & $\leq 15$ \\
\hline 3 & 9 & (TBP) & 55 & 42 & $25.0 \pm 0.5$ & $5.5 \times 10^{-7}-1.0 \times 10^{-3}$ & $3.5 \times 10^{-7}$ & $\leq 12$ \\
\hline 0.5 & 10 & (DBP) & 55 & 44.5 & $24.0 \pm 0.5$ & $7.9 \times 10^{-7}-5.0 \times 10^{-3}$ & $6.3 \times 10^{-7}$ & $\leq 12$ \\
\hline 1 & 11 & (DBP) & 55 & 44 & $26.5 \pm 0.5$ & $6.5 \times 10^{-7}-2.0 \times 10^{-3}$ & $4.0 \times 10^{-7}$ & $\leq 12$ \\
\hline 3 & 12 & (DBP) & 55 & 42 & $27.0 \pm 0.5$ & $7.2 \times 10^{-7}-5.0 \times 10^{-3}$ & $5.5 \times 10^{-7}$ & $\leq 15$ \\
\hline \multicolumn{9}{|l|}{ Zn-ATSC } \\
\hline 0.5 & 13 & (TCP) & 55 & 44.5 & $24.7 \pm 0.5$ & $5.0 \times 10^{-7}-6.3 \times 10^{-3}$ & $1.5 \times 10^{-7}$ & $\leq 15$ \\
\hline $1.0^{*}$ & 14 & $(\mathrm{TCP})$ & 55 & 44 & $28.5 \pm 0.5^{*}$ & $6.3 \times 10^{-8}-7.9 \times 10^{-3}$ & $5.0 \times 10^{-8}$ & $\leq 10$ \\
\hline 3 & 15 & (TCP) & 55 & 42 & $28.0 \pm 0.5$ & $1.5 \times 10^{-7}-1.0 \times 10^{-3}$ & $7.9 \times 10^{-8}$ & $\leq 10$ \\
\hline 0.5 & 16 & (DOP) & 55 & 44.5 & $27.0 \pm 0.5$ & $7.8 \times 10^{-7}-6.3 \times 10^{-3}$ & $6.3 \times 10^{-7}$ & $\leq 15$ \\
\hline 1 & 17 & (DOP) & 55 & 44 & $25.5 \pm 0.5$ & $5.0 \times 10^{-7}-5.0 \times 10^{-3}$ & $4.0 \times 10^{-7}$ & $\leq 12$ \\
\hline 3 & 18 & (DOP) & 55 & 42 & $26.5 \pm 0.5$ & $2.0 \times 10^{-7}-5.0 \times 10^{-3}$ & $1.0 \times 10^{-7}$ & $\leq 15$ \\
\hline 0.5 & 19 & (TBP) & 55 & 44.5 & $23.5 \pm 0.5$ & $8.9 \times 10^{-7}-5.0 \times 10^{-3}$ & $5.0 \times 10^{-7}$ & $\leq 15$ \\
\hline 1 & 20 & (TBP) & 55 & 44 & $24.5 \pm 0.5$ & $7.8 \times 10^{-7}-4.3 \times 10^{-3}$ & $5.3 \times 10^{-7}$ & $\leq 15$ \\
\hline 3 & 21 & (TBP) & 55 & 42 & $24.0 \pm 0.5$ & $5.0 \times 10^{-7}-1.0 \times 10^{-3}$ & $3.1 \times 10^{-7}$ & $\leq 15$ \\
\hline 0.5 & 22 & (DBP) & 55 & 44.5 & $19.0 \pm 0.5$ & $6.3 \times 10^{-6}-5.0 \times 10^{-3}$ & $4.6 \times 10^{-7}$ & $\leq 15$ \\
\hline 1 & 23 & (DBP) & 55 & 44 & $20.0 \pm 0.5$ & $5.0 \times 10^{-6}-7.8 \times 10^{-3}$ & $2.5 \times 10^{-7}$ & $\leq 15$ \\
\hline 3 & 24 & (DBP) & 55 & 42 & $20.0 \pm 0.5$ & $1.0 \times 10^{-6}-1.0 \times 10^{-3}$ & $8.9 \times 10^{-7}$ & $\leq 20$ \\
\hline \multicolumn{9}{|c|}{ Response characteristics of the $\mathrm{Zn}$-Complexes sensors } \\
\hline Parameters & \multicolumn{4}{|c|}{ Sensor 1} & \multicolumn{4}{|c|}{ Sensor 2} \\
\hline Sensors & \multicolumn{4}{|c|}{ Zn-TSC } & \multicolumn{4}{|c|}{ Zn-ATSC } \\
\hline Composition & \multicolumn{4}{|c|}{$1.0 \%(I . P)$} & \multicolumn{4}{|c|}{$1.0 \%(I . P)$} \\
\hline$(\mathrm{W} / \mathrm{W} \%)$ & \multicolumn{4}{|c|}{$+55.0 \% \mathrm{G}+44.0 \% \mathrm{P}$} & \multicolumn{4}{|c|}{$+55.0 \% \mathrm{G}+44.0 \% \mathrm{P}$} \\
\hline Slope (mV/decade) & \multicolumn{4}{|c|}{$32.5 \pm 0.5$} & \multicolumn{4}{|c|}{$28.5 \pm 0.5$} \\
\hline Correlation coefficient $(r)$ & \multicolumn{4}{|c|}{0.999} & \multicolumn{4}{|c|}{0.998} \\
\hline $\operatorname{LOD}(\mathrm{M})$ & \multicolumn{4}{|c|}{$2.5 \times 10^{-8}$} & & $5.0 x$ & & \\
\hline Linear range $(\mathrm{M})$ & & $5.0 \times$ & $\times 10^{-3}$ & & & $6.3 \times 10^{-8}-$ & & \\
\hline Working $\mathrm{pH}$ range & & & & & & $3.5-$ & & \\
\hline Response time (s) & & & & & & $\leq 10$ & & \\
\hline Recovery $(\%) \pm S . D^{*}$ & & & & & & 98.75 & & \\
\hline Robustness & & & & & & 99.40 & & \\
\hline Ruggedness & & & & & & 99.50 & & \\
\hline
\end{tabular}

G: graphite, B: binder, S: slope (mV/decade); C.R.: concentration range (M); LOD: limit of detection; R(s): response time (s). ${ }^{*}$ The selected sensor at $95 \%$ confidence intervals, average of five replicates at $25.0 \pm 0.1^{\circ} \mathrm{C}$

Table 1: Effect of binders on composition and characteristics of sensors (Zn-TSC) and (Zn-ATSC). 
Citation: Khorshid AF, Issa YM, Ami RR (2015) A Modified Carbon Paste Sensor for Determination of Zn in Vitamin and Waste Water using Thiosemicarbazide and Acetaldehyde Thiosemicarbazone Complexes. J Biosens Bioelectron 6: 176. doi:10.4172/2155-6210.1000176

Page 5 of 8

\begin{tabular}{|c|c|c|}
\hline Sensors & \multicolumn{2}{|c|}{ Standard deviation S.D } \\
\hline Zn-Sensors & $\mathbf{1 . 0} \times \mathbf{1 0}^{-4}$ & $\mathbf{1 . 0} \times \mathbf{1 0}^{-\mathbf{3}}$ \\
\hline $\mathbf{( 1 )}$ Zn-TSC & 0.33 & 0.45 \\
\hline $\mathbf{( 2 )}$ Zn-ATSC & 0.28 & 0.67 \\
\hline
\end{tabular}

Table 2: The standard deviation values for five replicate measurements of measuring emf obtained for each sensor.

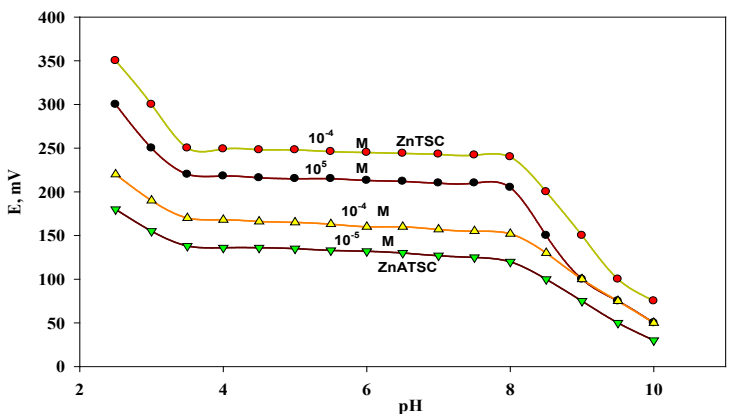

Figure 4: Effect of $\mathrm{pH}$ on the potential response for Zn TSC and ZnATSC sensors.

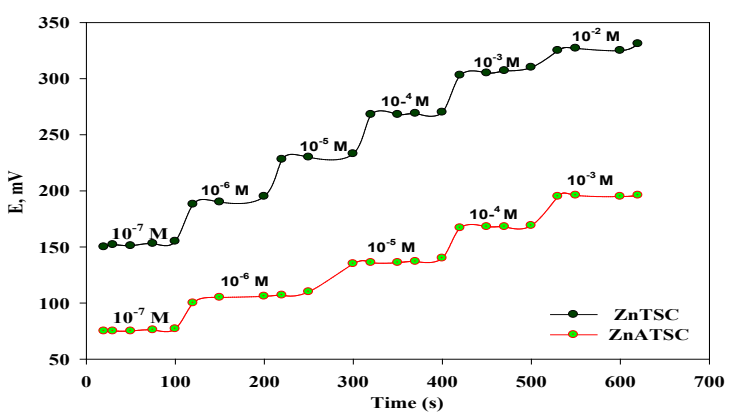

Figure 5: Potential-Time response of ZnTSC and ZnATSC/CMCP sensors.

\section{Effect of $\mathbf{p H}$}

The potential $\mathrm{pH}$ profile obtained indicates that the $\mathrm{pH}$ covering the range 3.5-8.0 responses of the sensors are fairly constant where in this range the sensor can be safely used for $\mathrm{Zn}$ determination. Therefore, for quantitative measurements with CMCP sensors, to reach the optimum experimental conditions the $\mathrm{pH}$ range from 3.5-8.0 was assumed to be the working $\mathrm{pH}$ range of the sensors. From Figure 4, it can be seen that there is no need to adjust the $\mathrm{pH}$ or use buffer solution at that $\mathrm{pH}$ values while, the $\mathrm{pH}$ lower than 3.5 , the readings of potential increase which can be related to hydronium ion interfering. In addition, at $\mathrm{pH}$ values higher than $\mathrm{pH} 8$, the potential readings decrease gradually due to the formation of free base of zinc and decrease of the protonated species in the test solutions as shown in Figure 4.

\section{Dynamic response time}

The dynamic response time [34] for the sensors was obtained by recording the time required to achieve a steady-state potential (within $\pm 1 \mathrm{mV}$ ) after subsequence immersions of the sensor in a series of drug concentration solutions from $1.0 \times 10^{-7}$ to $1.0 \times 10^{-2} \mathrm{M}$, each having a 10 fold increase in. The sensor was reached steady potential within less than ten s. This is most probably due to the fast exchange kinetics of association-dissociation of zinc ion with the complex at the solution- paste interface. The potential-time plot for the response of the sensor $\mathrm{Zn}$-CMCPs is shown in Figure 5.

\section{Selectivity of the sensor}

Table 3 is the selectivity coefficients which reflected the relative response of the paste sensor for the primary ion over other ions present in the solution and indicated highly selective and sensitive to zinc ion. Most of inorganic cations do not interfere due to the difference in their mobility and permeability as compared to zinc ion. In the case of amino acids and sugars the high selectivity is related to the difference in lipophilic nature and polarity of their molecules relative to zinc ion. As can be seen, the selectivity coefficients determined by MPM is sufficiently smaller than 1.0 indicating that the (Zn-TSC, Zn-ATSC) sensors are significantly selective to zinc ion over all the interfering ions.

\section{Validation of the proposed method}

Linearity and detection limit (LOD): For the optimal experimental CMCPS conditions, exists a linear relationship between the sensor potential $/ \mathrm{mV}$ and the logarithm of corresponding concentration of the zinc ion, the value of LOD was indicating that the proposed method is sensitive for detection of very small concentrations of $\mathrm{Zn}$ reach to 0.25 and $0.5 \mathrm{nM}$ for ZnTSC and ZnATSC respectively. The correlation coefficient (r) and other statistical parameters were listed in Table 1.

Accuracy: The accuracy of the proposed Zn-CMCPS method was investigated by the determination of $\mathrm{Zn}$ in its pure state and its vitamin form without interfering from the co formulated adjuvant as indicated and the mean recovery value are shown in Table 1 for the investigated Zn-CMCP sensors.

Precision: The precision measured as percentage relative standard deviation (\% RDS) for the Zn-CMCPS method and was tested by repeating the proposed CMCPS method for analysis of the investigated zinc ion in intra-day (within the day) and inter-day (consecutive days) to five replicates. The obtained \%RSD values were listed in Table 1 for the $\mathrm{Zn}-\mathrm{CMCP}$ sensors. The\% RSD values are less than $2 \%$, indicating good precision.

Robustness and ruggedness: The examination of robustness method for Zn-CMCPS was found by changed the aqueous solution to acetate buffer $\mathrm{pH} 4 \pm 0.5$ and the percentage result of robustness as in Table 1 . While the ruggedness or the reproducibility was examined by using another model of pH-meter (Jenway, 3505) the results obtained

\begin{tabular}{|c|c|c|c|c|c|}
\hline \multirow{2}{*}{$\begin{array}{c}\text { Interfering } \\
\text { ions }\end{array}$} & \multicolumn{2}{|c|}{ MPM } & \multirow{2}{*}{ Interfering ions } & \multicolumn{2}{c|}{ MPM } \\
\cline { 2 - 3 } & Zn-TSC & Zn-ATSC & & Zn-TSC & Zn-ATSC \\
\hline $\mathrm{Na}^{+}$ & 3.56 & 3.26 & $\mathrm{Ba}^{2+}$ & 3.72 & 3.55 \\
\hline $\mathrm{K}^{+}$ & 3.76 & 3.42 & $\mathrm{Al}^{3+}$ & 4.32 & 4.21 \\
\hline $\mathrm{NH}_{4}^{+}$ & 3.95 & 3.67 & $\mathrm{Cr}^{3+}$ & 3.65 & 3.48 \\
\hline $\mathrm{Ca}^{2+}$ & 4.22 & 3.85 & $\mathrm{Cu}^{2+}$ & 3.43 & 3.27 \\
\hline $\mathrm{Cd}^{2+}$ & 4.1 & 3.89 & $\mathrm{~Pb}^{2+}$ & 4.11 & 3.95 \\
\hline $\mathrm{Co}^{2+}$ & 4.3 & 3.94 & Glucose & - & - \\
\hline $\mathrm{Fe}^{2+}$ & 2.75 & 2.69 & Sucrose & - & - \\
\hline $\mathrm{Fe}^{3+}$ & 3.55 & 3.45 & Fractose & - & - \\
\hline $\mathrm{Ni}^{2+}$ & 4.23 & 4.17 & Maltose & - & - \\
\hline $\mathrm{Mn}^{2+}$ & 3.91 & 3.74 & L-Histidine & - & - \\
\hline $\mathrm{Mg}^{2+}$ & 3.88 & 3.79 & L-Cysteine & - & - \\
\hline $\mathrm{Cr}^{2+}$ & 3.76 & 3.63 & Glycine & - & - \\
\hline & & & & & \\
\hline
\end{tabular}

Table 3: Selectivity coefficient values for $-\log K_{\left.Z_{n}\right]^{z+}}^{\text {pot }}$ (Zn-TSC, Zn-ATSC)/ CMCPS. 
Citation: Khorshid AF, Issa YM, Ami RR (2015) A Modified Carbon Paste Sensor for Determination of Zn in Vitamin and Waste Water using Thiosemicarbazide and Acetaldehyde Thiosemicarbazone Complexes. J Biosens Bioelectron 6: 176. doi:10.4172/2155-6210.1000176

Page 6 of 8

\begin{tabular}{|c|c|c|c|c|c|c|c|c|c|c|}
\hline \multirow{2}{*}{\multicolumn{6}{|c|}{ Standard addition method }} & \multirow{2}{*}{\multicolumn{5}{|c|}{$\begin{array}{l}\text { Potentiometric titration } \\
\text { EDTA as titrant }\end{array}$}} \\
\hline & & & & & & & & & & \\
\hline \multirow{2}{*}{$\begin{array}{c}\text { Pure } \\
\text { solutions }\end{array}$} & \multirow{2}{*}{$\begin{array}{l}\text { Official(1) } \\
\text { method }\end{array}$} & \multicolumn{2}{|c|}{ Sensor 1} & \multicolumn{2}{|c|}{ Sensor 2} & \multicolumn{3}{|c|}{ Sensor 1} & \multicolumn{2}{|c|}{ Sensor 1} \\
\hline & & \multicolumn{2}{|c|}{ Zn-TSC } & \multicolumn{2}{|c|}{ Zn-ATSC } & \multicolumn{3}{|c|}{ Zn-TSC } & \multicolumn{2}{|c|}{ Zn-ATSC } \\
\hline \multicolumn{2}{|c|}{ Taken $(\mathrm{mg})$} & $\mathrm{R}(\%)$ & R.S.D\% & $\mathrm{R}(\%)$ & R.S.D\% & Taken (mg) & $\mathbf{R}(\%)$ & R.S.D\% & $\mathbf{R}(\%)$ & R.S.D\% \\
\hline 1.79 & \multirow{6}{*}{$98.0 \pm 0.50$} & 99.4 & 0.35 & 98.64 & 0.35 & 5.38 & 99.37 & 0.21 & 99.2 & 0.11 \\
\hline 2.69 & & 99.25 & 0.47 & 99 & 0.47 & 8.97 & 99.78 & 0.27 & 99.45 & 0.26 \\
\hline 3.59 & & 99 & 0.48 & 98.5 & 0.48 & 12.56 & 99.69 & 0.3 & 99.36 & 0.33 \\
\hline$X \pm S . E$ & & \multicolumn{2}{|c|}{$99.22 \pm 0.05$} & \multicolumn{2}{|c|}{$98.43 \pm 0.05$} & \multicolumn{3}{|c|}{$99.61 \pm 0.05$} & \multicolumn{2}{|c|}{$99.34 \pm 0.05$} \\
\hline $\mathrm{F}$ value & & \multicolumn{2}{|c|}{2.35} & \multicolumn{2}{|c|}{2.25} & \multicolumn{3}{|c|}{1.73} & \multicolumn{2}{|c|}{1.59} \\
\hline $\mathrm{t}$ value & & \multicolumn{2}{|c|}{2.55} & \multicolumn{2}{|c|}{2.4} & \multicolumn{3}{|c|}{2.16} & \multicolumn{2}{|c|}{2.38} \\
\hline \multicolumn{11}{|c|}{ Octozinc (25 mg) } \\
\hline 2.69 & \multirow{6}{*}{$102.5 \pm 0.5$} & 100.5 & 0.55 & 100.7 & 0.87 & 3.59 & 100.4 & 0.36 & 101.3 & 0.44 \\
\hline 3.59 & & 101.2 & 0.41 & 101.5 & 1.05 & 5.38 & 101.2 & 0.26 & 101.7 & 0.38 \\
\hline 5.38 & & 101.8 & 0.53 & 101.9 & 1.25 & 8.97 & 102.1 & 0.39 & 102.1 & 0.56 \\
\hline$X \pm S . E$. & & \multicolumn{2}{|c|}{$101.20 \pm 0.05$} & \multicolumn{2}{|c|}{$101.42 \pm 0.52$} & \multicolumn{3}{|c|}{$101.33 \pm 0.05$} & \multicolumn{2}{|c|}{$101.7 \pm 0.05$} \\
\hline $\mathrm{F}$ value & & & & & & & 1.66 & & & \\
\hline $\mathrm{t}$ value & & & & & & & 2.14 & & & \\
\hline & & & & Waste & & & & & & \\
\hline 2.69 & & 98.5 & 0.36 & 98.3 & 0.42 & - & - & - & - & - \\
\hline 3.59 & & 98.3 & 0.27 & 98 & 0.38 & - & - & - & - & - \\
\hline$X \pm S . E$. & $98.0 \pm 0.50$ & & .05 & & 0.05 & & -- & & & \\
\hline$F$ value & & & & & & & -- & & & \\
\hline $\mathrm{t}$ value & & & & & & & -- & & & \\
\hline
\end{tabular}

Table 4: Determination of Zn-CMCPs applying the standard addition method, potentiometric titration in pure solution, Octozinc (25 mg), spiked waste water and its statistical data treatments in comparison with official methods.

\begin{tabular}{|c|c|c|c|c|c|c|}
\hline $\begin{array}{c}\text { S. } \\
\text { no }\end{array}$ & $\begin{array}{c}\text { Response range } \\
\mathbf{( M )}\end{array}$ & $\begin{array}{c}\text { Slope }(\mathbf{m V} / \\
\text { decade) }\end{array}$ & $\mathbf{p H}$ range & $\begin{array}{c}\text { Detection } \\
\text { limit }\end{array}$ & \begin{tabular}{c} 
Response \\
\cline { 5 - 6 }
\end{tabular} & References \\
\hline 1 & $2.9 \times 10^{-7}-3.2 \times 10^{-7}$ & 29.9 & $2.0-9.0$ & $2.7 \times 10^{-7}$ & $<15$ & \\
\hline 2 & $1.0 \times 10^{-6}-1.0 \times 10^{-1}$ & 30 & $3.2-7.1$ & $8.9 \times 10^{-7}$ & $<10$ & 24 \\
\hline 3 & $1.3 \times 10^{-7}-1.0 \times 10^{-1}$ & 29.2 & $3.5-9.2$ & $1.0 \times 10^{-8}$ & $<10$ & 26 \\
\hline 4 & $1.0 \times 10^{-6}-1.0 \times 10^{-1}$ & 29 & $4.0-12.0$ & $1.0 \times 10^{-7}$ & $<20$ & 28 \\
\hline 5 & $5.0 \times 10^{-8}-2.0 \times 10^{-3}$ & 32.5 & $3.5-8.0$ & $0.25 \mathrm{nM}$ & $<10$ & CMCPS \\
\hline 6 & $6.3 \times 10^{-8}-7.9 \times 10^{-3}$ & 28.5 & $3.5-8.0$ & $0.50 \mathrm{nM}$ & $<10$ & CMCPS \\
\hline
\end{tabular}

Table 5: Comparison of response characteristic of Zn-CMCP sensor with some previous reported electrode.

was indicated the high robustness and ruggedness as percentage in Table 1.

Content uniformity assay of octozinc: The proposed Zn-CMCP sensors method described good validation with accuracy and precision for the quality control tests, the content uniformity assay showed accurate and reproducible results so the sensors can be employed for quantification of zinc and the recovery of zinc ion is almost quantitative.

\section{Analytical applications}

The standard addition method for the determination of zinc ion was proved to be successfully applied in its pure solutions, Octozinc (25 mg/capsule) and biological waste water using its prepared $\mathrm{Zn}$ chemically modified carbon paste sensors.

Determination of octozinc ( $25 \mathrm{mg} /$ capsule): In order to assess the validity of the proposed sensor, the proposed $\mathrm{Zn}$-CMCP sensors were used successfully using the standard additions method [30] and the potentiometric titration method for the determination of $\mathrm{Zn}$ ion in its pure solutions, capsule and the waste water. It is clear from the results, given in Table 4, that there is good agreement between the results of the

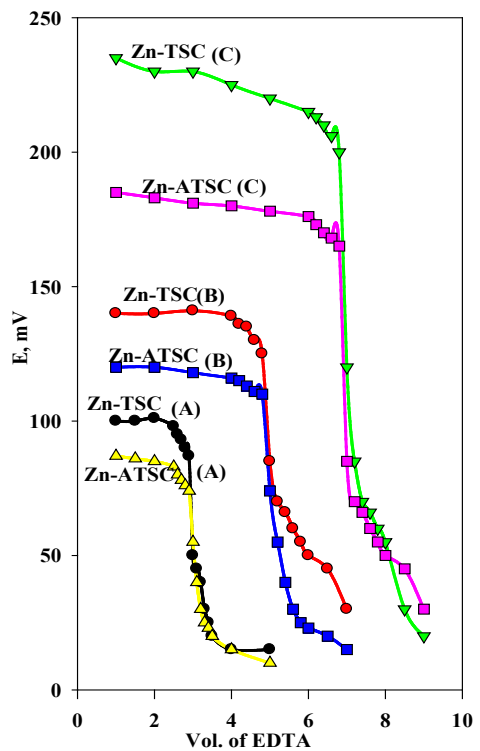

Figure 6: Potentiometric titration of (A) 2.69 (B) 4.49 and (C) $6.28 \mathrm{mg}$ respectively of $1.0 \times 10^{-2} \mathrm{M} \mathrm{ZnSO}_{4} \cdot \mathrm{H}_{2} \mathrm{O}$ with standard solution of $1.0 \times 10^{-2} \mathrm{M}$ of EDTA.

proposed sensor and those obtained from US Pharmacopeia method.

Determination of $\mathrm{Zn}$ in spiked waste water: The proposed of $\mathrm{Zn}$ CMCPS method was successfully applied for determination of $\mathrm{Zn}$ in spiked waste water and the results obtained with high precision and accuracy as summarized in Table 4 . In spiked waste water samples the standard addition technique was applied to overcome the matrix effects 
Citation: Khorshid AF, Issa YM, Ami RR (2015) A Modified Carbon Paste Sensor for Determination of Zn in Vitamin and Waste Water using Thiosemicarbazide and Acetaldehyde Thiosemicarbazone Complexes. J Biosens Bioelectron 6: 176. doi:10.4172/2155-6210.1000176

Page 7 of 8

in these samples. In addition, the response times of the proposed sensors are instant (within $10 \mathrm{~s}$ ), so the sensors are rapidly transferred forth and back between the samples and the bi-distilled water for washing between the measurements to protect the sensing component from adhering to the surface of some matrix components. It is concluded that the proposed Zn-CMCP sensors can be successfully applied in spiked waste water samples and this confirms that the sensitivity and limit of quantification (LOQ) are adequate for determination of zinc ion.

Potentiometric titration of zinc ion with a standard EDTA solution using Zn-TSC and Zn-ATSC sensors: The Zn-TSC and ZnATSC sensors were successfully applied as an indicator in titration of (1-10) $\mathrm{ml} \mathrm{ZnSO}_{4} \cdot \mathrm{H}_{2} \mathrm{O}\left(1.0 \times 10^{-2} \mathrm{M}\right)$ with a standard EDTA solution $\left(1.0 \times 10^{-2} \mathrm{M}\right)$. The resulting titration curve is shown in Figure 6 . The amount of $\mathrm{Zn}$ ions in its solution could be accurately determined with the sensors Zn-TSC and Zn-ATSC very well. The end point of the titration is sharp and the amount of $\mathrm{Zn}$ ions in solution can be accurately determined with the sensors. The fast and sharp end point can be explained by the fact that these sensors contain carbon particles surrounded by a very thin film of TCP and acting as a conductor and the absence of the internal reference solution.

\section{Statistical treatment of results}

The results of the recoveries of $\mathrm{Zn}$ applying the standard additions method and the potentiometric titration were evaluated statistically and compared with the values obtained with the pharmacopeia method by applying the F-tests $[34,35]$. As shown in Table 4 that the present methods had a precision comparable to that of the pharmacopeia method. However, the proposed methods were more practical regarding time of analysis, consumption of solvents and sample pretreatment requirements for ion selective electrode for the analysis of zinc ion.

\section{Potentiometric monitoring of octozinc dissolution}

The dissolution test showed that zinc capsule released immediately after capsule was ruptured. More than $75 \%$ zinc was released within 15 $\mathrm{sec}$ and complete dissolution was achieved in $20 \mathrm{sec}$.

The potentiometric method, the potential values were continuously recorded at 1-2 sec time intervals and compared with a calibration graph. For the conductimetric measurements, introduce the conductmetric electrode in the vessel every two seconds without hindering the

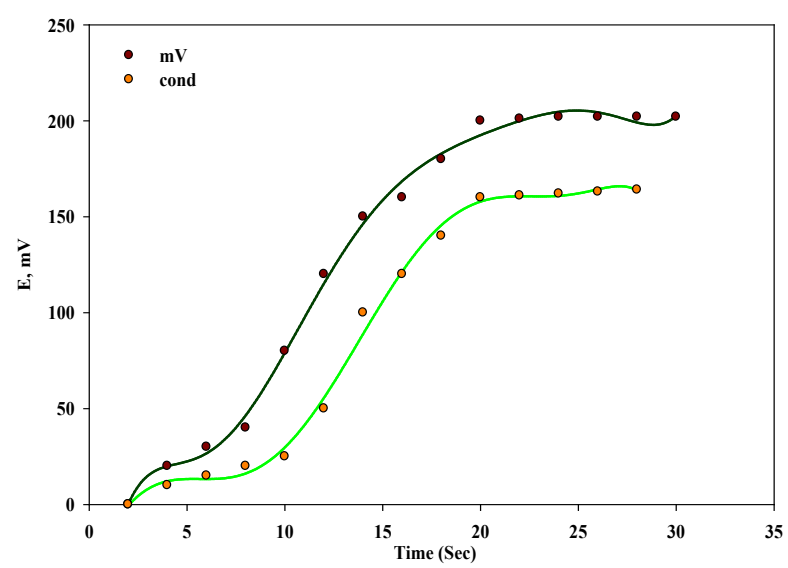

Figure 7: Dissolution profile of $25 \mathrm{mg}$ zinc capsule obtained by conductimetric and CMCPS potentiometric methods. motion and take the reading by $\mu$ s and compared with a calibration graph. Figure 7 showed the dissolution profiles of zinc capsule using both measurement techniques. The results obtained by two methods are almost identical. The use of the potentiometric method sensor, however, has the advantage of in situ monitoring.

\section{Comparison of the zinc selective sensors}

The comparison of the performance characteristics of the proposed sensors and those of some reported ISE method were presented in Table 5. It is clear that the proposed sensor CMCPS was the most wide linear range and the response time improved with respect to those the previously reported in zinc-selective electrodes. Its detection limit was lower than found for the other electrodes those in the reference.

\section{Conclusion}

The proposed potentiometric methods based on the construction of CMCP sensors with Zn-complexes might be useful analytical characteristics for the determination of zinc in its pure solutions, pharmaceutical dosage form and waste water. The good recoveries and low relative standard deviations obtained reflect the high accuracy and precision of the proposed method. Moreover, the CMCPS is simple in fabrication and construction, high sensitivity sensor, easy to operate in mechanism, and fast static response dynamic time, reasonable selectivity for variables ions, long term stability for zinc ion solution and applicability over a wider concentration range with minimal sample pretreatment and inexpensive making it an excellent tool for the routine determination of $\mathrm{Zn}$ in quality control laboratories. The sensor developed is superior as compared with the zinc selective sensor described in the literature.

\section{Acknowledgement}

I gratefully acknowledge the support of National Organization for drug control and research (NODCAR) in Giza-Egypt, by the chemicals and dissolution equipment also acknowledge the supporting of Central Research Lab at Nahda University with the other equipments at the practical work.

\section{References}

1. Bao B, Prasad AS, Beck FW, Fitzgerald JT, Snell D, et al. (2010) Zinc decreases C-reactive protein, lipid peroxidation, and inflammatory cytokines in elderly subjects: A potential implication of zinc as an atheroprotective agent. Am J Clin Nutr 91(6): 1634-1641.

2. Li Q, Zhao XH, Lv QZ, Liu GG (2007) The determination of zinc in water by flame atomic absorption spectrometry after its separation and preconcentration by malachite green loaded microcrystalline triphenylmethane. Sep Purif Technol 55: 76-81

3. Kaur P, Kaur S, Mahajan A, Singh K (2008) Highly selective colorimetric sensor for $\mathrm{Zn}^{2+}$ based on hetarylazo derivative. Inorg Chem Commun 11: 626-629.

4. Gupta NR, Mittal S, Kumar S, Kumar SKA (2008) Potentiometric studies of $N, N$ '-Bis(2-dimethylaminoethyl)- $N, N^{\prime}$-dimethyl-9,10 anthracenedimethanamine as a chemical sensing material for $\mathrm{Zn}(\mathrm{II})$ ions. Mater Sci Eng C 28: 1025-1030.

5. Hosseini M, Vaezi Z, Ganjali MR, Faridbod F, Abkenar SD, et al. (2010) Fluorescence "turn-on" chemosensor for the selective detection of zinc ion based on Schiff-base derivative. Spectrochim Acta A 75: 978-982.

6. Ma QJ, Zhang XB, Zhao Y, Li CY, Han ZX, et al. (2009) A fluorescent probe for zinc ions based on $\mathrm{N}$-methyltetraphenyprophine with high selectivity. Spectrochim. Acta A 71: 1683-1687.

7. Wilhartitz P, Dreer S, Krismer R, Bobleter O (1997) High performance ultratrace analysis in molybdenum and tungsten accomplished by on-line coupling of ion chromatography with simultaneous ICP-AES. Microchim Acta 125: 45-52.

8. Gorton L, Fiedler U (1977) A zinc-selective polymeric membrane sensor. Anal Chim Acta 90: 233-236.

9. Linnersund UF, Bhatti KM (1979) Development of polymeric membranes for zinc ion-selective sensors Anal Chim Acta 111: 57-70. 
Citation: Khorshid AF, Issa YM, Ami RR (2015) A Modified Carbon Paste Sensor for Determination of Zn in Vitamin and Waste Water using Thiosemicarbazide and Acetaldehyde Thiosemicarbazone Complexes. J Biosens Bioelectron 6: 176. doi:10.4172/2155-6210.1000176

10. Kogima R, Kamata S (1994) Zinc-selective membrane sensor using tetrabutylthiuram disulfide neutral carrier. Anal Sci 10: 409-412.

11. Srivastava SK, Vardhan H, Singh M, Rao GN, Srivastava S (1995) A new chelating ion-exchange resin based sensor for zinc ions. Anal Proc 32: 173-174.

12. Singh AK, Bhattacharjee G, Singh M, Chandra S (1997) A new macrocyclic polystyrene based membrane sensor for zinc. Electroanalysis 9: 1005-1008.

13. Gupta VK, Jain AK, Singh LP, Khurana U (1998) $\mathrm{Zn}^{2+}$ sensor based on $\mathrm{Zn}$ bis(2,4,4-trimethylpentyl)dithiophosphinic acid complex in PVC matrix. Electrochim Acta 43: 2047-2052.

14. Gupta VK (1999) A PVC based 12-crown-4 membrane potentiometric sensor for zinc (II) ions. Sens Actuators B 55: 195-200.

15. Shamsipur M, Rouhani S, Ganjali MR, Sharghi H, Eshgi H (1999) Zincselective membrane potentiometric sensor based on a recently synthesized benzo-substituted macrocyclic diamide. Sens Actuators B 59: 30-34.

16. Fakari AR, Alaghemand $M$, Shamsipur $M$ (2000) Zinc-selective membrane sensor based on 5,6,14,15-dibenzo-1,4-dioxa-8,12- diazacyclopentadecane5,14-diene. Anal Lett 33: 2169-2181.

17. Gupta VK, Jain AK, Mangla R, Kumar $P$ (2001) A new $\mathrm{Zn}^{2+}$ selective sensor based on 5,10,15,20-tetraphenyl-21H, 23H-porphine in PVC matrix. Electroanalysis 13: 1036-1040.

18. Jain AK, Sondhi SM, Rajvanshi S (2002) A PVC based hematoporphyrin IX membrane potentiometric sensor for Zn(II). Electroanalysis14: 293-296.

19. Gupta VK, Chauhan DK, Saini VK, Agarwal S, Antonijevic MM, et al. (2003) A porphyrin based potentiometric sensor for $\mathrm{Zn}^{2+}$ determination. Sensors 3: 223-235.

20. Gupta VK, Khayat MAl, Minocha AK, Kumar P (2005) Zinc(II)- selective sensors based on dibenzo-24-crown-8 in PVC matrix. Anal Chim Acta 532: 153-158.

21. Ganjali MR, Zamani HA, Norouzi P, Adib M, Rezapour M, et al. (2005) $\mathrm{Zn}^{2+}$ PVC-based membrane sensor based on 3-[(2-Furylmethylene) amino]-2thioxo-1, 3-thiazolidin-4-one. Bull Kor Chem Soc 26: 579-584.

22. Gupta VK, Agarwal S, Jakob A, Lang H (2006) A zinc-selective sensor based on $N, N^{\prime}$-bis(acetylacetone)ethylenediimine. Sens Actuators B 114: 812-818.

23. Singh AK, Jain AK, Saxena P, Mehtab S (2006) Zn (II)-selective membrane electrode based on tetraazamacrocycle [Bzo2Me2Ph2 (16) hexaeneN4]. Electroanalysis 18: 1186-1192.
24. Chandra S, Singh DR (2010) Zinc(II) selective poly(vinyl chloride) membrane ISE using a macrocyclic compound 1,12,14-triaza-5,8-dioxo-3(4),9(10)dibenzoylcyclopentadeca-1,12,14-triene as neutral carrier. Journal of Saudi Chemical Society 14: 55-60.

25. Gupta VK, Ganjali MR, Norouzi P, Khani H, Nayak A, et al. (2011) Electrochemical Analysis of Some Toxic Metals by lon-Selective Sensors. Crit Rev Anal Chem 41: 282-313.

26. Singh $P$, Singh AK, Jain AK (2011) Electrochemical sensors for the determination of $\mathrm{Zn}^{2+}$ ions based on pendant armed macrocyclic ligand. Electrochimi Acta 56: 5386-5395.

27. Al-Asousi MF, Shoukry AF, Bu-Olayan AH (2012) Halogen-free ionic liquid as an additive in zinc(II)-selective electrode: Surface analyses as correlated to the membrane activity Talanta: 94: 184-188.

28. Md Isa I, Noor SM, Juahir Y, Hashim N, Ahmad M, et al. (2014) Zinc(II) Selective Electrode based on Polymeric Membrane of 2,6-Diacetylpyridinebis(benzenes ulfonylhydrazide) Ligand. Int J Electrochem Sci 9: 4512-4522.

29. Umezawa Y, Buhlmann P, Umezawa K, Tohda K, Amemiya S (2000) Potentiometric selectivity coefficients of ion-selective sensors. Part I. Inorganic cations (technical report). Pure Appl Chem 72: 1851-2082.

30. Umezawa Y, Umezawa K, Sato H (1995) Selectivity coefficients for ionselective sensors: Recommended methods for reporting KA,B pot values (technical report). Pure Appl Chem 67: 507-511.

31. Guilbault G, Drust RA, Frant MS, Freiser H, Hansen, et al. (1976) Recommendations for nomenclature of ion-selective sensors. Pure Appl Chem 48: 127-129.

32. United States Pharmacopeia, National Formulary USP 30-NF 25 Convention, Inc.: Rockville, MD, 2009.

33. Linder E, Umezawa $Y$ (2008) Performance evaluation criteria for preparation and measurement of macro- and micro fabricated ion-selective sensors. Pure Appl Chem 80: 85-104.

34. Skoog DA, Holler FJ, Neiman TA (1997) Principles of Instrumental Analysis (5thedn), Harcourt Brace College Publishers, London.

35. Miller JC, Miller JN (1994) Statistics for Analytical Chemistry, Ellis Horwood Chichester, England. 